\title{
Neuropatie polekowe
}

\author{
Drug-induced neuropathies

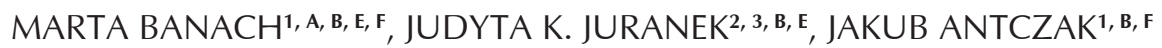 \\ ${ }^{1}$ Katedra Neurologii Uniwersytetu Jagiellońskiego Collegium Medicum w Krakowie \\ ${ }^{2}$ New York University Langone Medical Center, New York, USA \\ ${ }^{3}$ Katedra Patofizjologii Wydziału Nauk Medycznych Uniwersytetu Warmińsko-Mazurskiego w Olsztynie
}

A - przygotowanie projektu badania, B - zbieranie danych, C - analiza statystyczna, D - interpretacja danych,

E - przygotowanie maszynopisu, F - opracowanie piśmiennictwa, G - pozyskanie funduszy

Streszczenie Działania niepożądane leków stanowią najczęstszą przyczynę toksycznego uszkodzenia obwodowego układu nerwowego. Częstość ich występowania waha się od 10 do 100\% i zależy od rodzaju zastosowanego leku, długości terapii oraz obecności chorób towarzyszących. Neurotoksyczność polekowa stanowi jedną z najczęstszych przyczyn zmniejszania dawki terapeutycznej danego leku bądź całkowitego przerwania dotychczasowej terapii, osłabiając jej skuteczność i negatywnie wpływając na stan zdrowia pacjentów oraz generując dodatkowe koszty opieki zdrowotnej. W praktyce lekarskiej coraz częściej obserwuje się negatywnie oddziałujące na układ nerwowy objawy niepożądane podstawowych leków opieki medycznej, począwszy od leków stosowanych w zaburzeniach rytmu serca oraz obniżających poziom cholesterolu (amiodaron, statyny), przez leki stosowane w chorobach autoimmunologicznych (etanercept, infliksymab, leflunomid), przeciwpadaczkowe (fenytoina), przeciwzakaźne - bakteriobójcze, przeciwgrzybicze lub pierwotniakobójcze (nitrofurantoina, metronidazol, izoniazyd), aż do leków przeciwnowotworowych (talidomid, bortezomib, oksaliplatyna, cisplatyna, suramina, paklitaksel, winkrystyna i inne). Niewykryte i nieleczone neurotoksyczne objawy niepożądane leków mogą doprowadzić do trwałych zmian w obwodowym układzie nerwowym, upośledzając samodzielne funkcjonowanie pacjentów (doprowadzając niekiedy nawet do trwałego kalectwa), negatywnie oddziałując na przebieg terapii oraz na samopoczucie i stan psychiczny chorych. W niniejszej pracy skupimy się na kilku wybranych lekach z wymienionych wyżej kategorii, opisując skutki ich negatywnego oddziaływania na obwodowy układ nerwowy, co w znaczny sposób wpływa na stan zdrowia pacjentów.

Słowa kluczowe: neurotoksyczność, statyny, polekowe neuropatie, amiodaron, talidomid, bortezomib.

Summary Neurotoxicity is one of the most common side effects of many routinely used drugs, affecting the peripheral nervous system and impairing treatment efficiency. Drug-induced neurotoxicity ranges from $10 \%$ to $100 \%$ and depends on the medicine used, duration of therapy, and presence of concomitant disorders. Neurotoxic side effects have been increasingly reported by primary care physicians, affecting treatment and generating additional costs both for patients and for health care providers. Many of the most neurotoxic drugs are also the most widely used, often listed as essential medicines for the most common ailments and disorders, and include cardiovascular/blood pressure drugs (statins, amiodarone), drugs for autoimmune diseases (etanercept, infliximab, leflunomide), anticonvulsants (phenytoin), drugs for bacterial, protozoan, or viral infections (nitrofurantoin, metronidazole, isoniazid), and antineoplastic drugs (thalidomide, bortezomib, oxaliplatin, cisplatin, suramin, paclitaxel, vincristine, and others). Undetected and untreated drug-induced neurotoxic side effects trigger irreparable changes in peripheral nerves, affecting their function and resulting in physical disability of patients, worsening their well-being and altering the course of therapy. Dose reduction or the use of an equally effective but less neurotoxic drug allows to prevent polyneuropathy. In this paper, we aimed to provide a short review of selected neurotoxic drugs, describe the most prevalent neurotoxic symptoms.

Key words: neurotoxicity, statins, drug-induced neuropathies, amiodarone, thalidomide, bortezomib.

Fam Med Prim Care Rev 2015; 17(4): 284-288

\section{Wstęp}

Działania niepożądane leków są najczęstszą przyczyną toksycznego uszkodzenia obwodowego układu nerwowego. Częstość ich występowania waha się od 10 do 100\% [1, 2]. Obraz kliniczny i elektrofizjologiczny zmian neuropatycznych, ich rodzaj i nasilenie objawów zależą zazwyczaj od dawki leku, czasu trwania terapii, chorób współistniejących oraz indywidualnych różnic w metabolizmie [1, 2].

Działania neurotoksyczne leków stanowią jedną z najczęstszych przyczyn zmniejszania dawki terapeutycznej danego leku bądź całkowitego przerwania dotychczasowej terapii, osłabiając jej skuteczność, negatywnie wpływając na stan zdrowia pacjentów i generując dodatkowe koszty opieki zdrowotnej.
Wśród leków o nasilonym działaniu neurotoksycznym szczególne miejsce zajmują chemioterapeutyki oraz leki kardiologiczne. W niniejszej pracy skupimy się na kilku wybranych lekach z obu kategorii oraz opiszemy skutki ich negatywnego oddziaływania na układ nerwowy, co znacznie wpływa na stan zdrowia pacjentów.

\section{Etiologia i patogeneza neuropatii związanej z chemioterapią}

W wielu przypadkach znajomość mechanizmu działania leków pozwala na określenie mechanizmu patogenezy neuropatii. Zgodnie ze stanem dotychczasowej wiedzy możemy stwierdzić, że większość leków o działaniu neuro- 
toksycznym wpływa przede wszystkim na wypustki nerwowe, uszkadzając stadialną część aksonu; znacznie mniejsza liczba leków oddziałuje na ciała komórek nerwowych, komórki Schwanna czy osłonki mielinowe [3]. Wyniki badań histopatologicznych nerwów osób narażonych na neurotoksyny oraz badań eksperymentalnych na zwierzętach potwierdziły, że większość substancji neurotoksycznych, wpływając na transport aksonalny, powoduje zwyrodnienie aksonu o charakterze tzw. obumierania wstecznego (dying back) $[4,5]$.

W zależności od miejsca uszkodzenia neuropatie polekowe dzielimy na aksonopatie, mielinopatie oraz neuronopatie. Większość substancji neurotoksycznych powoduje uszkodzenia o charakterze aksonopatii, stosunkowo rzadko obserwuje się neuronopatie czy mielinopatie. W każdym przypadku stwierdzonej mielinopatii należy wykluczyć demielinizacyjne polineuropatie zapalne [4-6].

\section{Charakterystyka kliniczna}

Przykładem aksonopatii jest aksonalna polineuropatia czuciowo-ruchowa, która charakteryzuje się symetrycznym osłabieniem wszystkich rodzajów czucia na obszarze "rękawiczek" i "skarpetek". Zaburzenia czucia są zwykle bardziej nasilone niż osłabienie siły mięśni. Proces zdrowienia przebiega wolno.

Neuronopatie dotyczą zazwyczaj komórek nerwowych neuronów czuciowych zwojów korzeni grzbietowych rdzenia kręgowego. W obrazie klinicznym obserwuje się osłabienie bądź zaburzenie czucia, osłabienie koordynacji ruchowej (ataksję), allodynię oraz ból neuropatyczny [7]. Ten typ zmian neurotoksycznych występuje najczęściej u pacjentów nowotworowych leczonych chemioterapeutykami z grupy leków platynowych (oksaliplatyna, cisplatyna) [8].

W przypadku mielinopatii cechą charakterystyczną jest zazwyczaj symetryczne osłabienie siły mięśniowej rozpoczynające się dystalnie w kończynach dolnych, postępujące proksymalnie, a następnie obejmujące kończyny górne. U niektórych chorych wyraźnie przeważa osłabienie proksymalne i/lub asymetria objawów. W obrazie klinicznym niedowłady przeważają nad zaburzeniami czucia [3, 9]. Uszkodzenie cienkich włókien objawia się bólem, parestezjami oraz uczuciem pieczenia w odcinkach dystalnych kończyn. Zazwyczaj nie stwierdza się osłabienia siły mięśniowej ani istotnych zaburzeń innych rodzajów czucia. Parametry przewodzenia czuciowego i ruchowego są na ogół prawidłowe.

Uszkodzenie grubych włókien cechuje się natomiast zaburzeniami czucia ułożenia, zwykle nasilonymi w kończynach dolnych [9]. Uszkodzenie grubych włókien mielinowych oraz neuronów czuciowych występuje u pacjentów narażonych na cisplatynę, metronidazol, pirydoksynę oraz talidomid; charakteryzuje się osłabieniem odruchów głębokich, zaburzeniami czucia głębokiego, objawami pseudoatetozy i ataksją chodu [10].

\section{Charakterystyka elektrofizjologiczna}

Badanie elektrofizjologiczne pozwala potwierdzić polineuropatię oraz pomaga ocenić rozległość uszkodzenia, określić jego typ i śledzić dynamikę procesu chorobowego w kolejnych badaniach kontrolnych [9]. Uszkodzenie aksonalne charakteryzuje się obniżeniem amplitudy odpowiedzi czuciowej i ruchowej przy prawidłowej lub nieznacznie zwolnionej szybkości przewodzenia, zazwyczaj z objawami ostrego odnerwienia i/lub cechami reinerwacji w mięśniach odsiebnych, a w zaawansowanej postaci również w mięśniach proksymalnych [9, 11]. Znaczne zwolnienie szybkości przewodzenia we włóknach ruchowych i czucio- wych nerwów obwodowych wraz z wydłużeniem latencji końcowej oraz latencji fali $\mathrm{F}$ wskazuje na proces demielinizacyjny [9, 12]. Obraz elektrofizjologiczny polineuropatii toksycznych może być bardzo zróżnicowany, zwłaszcza gdy współistnieje uszkodzenie mięśni lub złącza nerwowo-mięśniowego.

Poniżej przedstawiono toksyczny wpływ wybranych leków na obwodowy układ nerwowy.

\section{Leki stosowane w kardiologii}

\section{Amiodaron}

Amiodaron jest skutecznym lekiem przeciwarytmicznym. $U$ niektórych chorych z zaburzeniami rytmu serca jest lekiem z wyboru [13].

Działa przeciwarytmicznie przez wydłużenie czasu trwania potencjału błonowego z jednoczesnym hamowaniem czwartej fazy potencjału czynnościowego (fazy polaryzacji) komórek mięśnia sercowego [13].

Zastosowanie tego leku mogą ograniczać liczne neurotoksyczne objawy niepożądane występujące z częstością od 5 do 74\% [14]. Najczęściej opisuje się drżenie zamiarowe o częstotliwości $6-10 \mathrm{~Hz}$, zwykle obustronne, symetryczne (39-43\%), często towarzyszące polineuropatii, oraz ataksję chodu (7-37\%) [15-17]. Znacznie rzadziej występują: encefalopatia, neuropatia nerwu wzrokowego oraz miopatia i rabdomioliza o piorunującym przebiegu [18-20].

Wystąpienie polineuropatii zależy zwykle od dawki leku oraz czasu trwania terapii [21-23], choć opisano również przypadki polineuropatii podczas stosowania przez miesiąc dawki 200 mg/d [24]. Polineuropatia może przebiegać w sposób ostry, podostry lub przewlekły. Przewlekłe stosowanie amiodaronu powoduje wystąpienie odsiebniej symetrycznej polineuropatii czuciowo-ruchowej. Opisano również przypadki dosiebnej asymetrycznej neuropatii ruchowej oraz ostro przebiegającej polineuropatii naśladującej zespół Guillaina i Barrégo, a także przypadki z proksymalnym wzorem osłabienia mięśni, okresowo występującej mialgii oraz z obecnością zmian miogennych w badaniu elektromiograficznym [16].

Badanie elektrofizjologiczne wykazuje zazwyczaj uszkodzenie aksonu, rzadziej proces demielinizacyjny. W badaniach elektroneurograficznych stwierdza się obniżenie amplitudy czuciowych nerwowych i złożonych mięśniowych potencjałów czynnościowych oraz nieznaczne wydłużenie latencji końcowych. Ruchowa i czuciowa szybkość przewodzenia jest prawidłowa lub nieznacznie zwolniona. Zmiany są najbardziej nasilone na dystalnych odcinkach nerwów [25-27]. W badaniu EMG wszystkie typowe cechy neuropatii aksonalnej są bardziej nasilone w mięśniach dystalnych. W postaci ostrej w badanych mięśniach elektrofizjologiczne objawy aktywnego odnerwienia w postaci fibrylacji i fal ostrych mogą przeważać nad cechami reinerwacji w postaci wysokiej amplitudy potencjałów jednostek ruchowych, wydłużonego czasu trwania, zwiększonego pola i wzrostu odsetka potencjałów wielofazowych. Niekiedy współistnieją zmiany miopatyczne w odcinkach proksymalnych mięśni (obecność krótkich polifazowych potencjałów o niskiej amplitudzie). Wynik biopsji nerwu najczęściej ujawnia zwyrodnienie aksonalne wszystkich typów włókien, rzadziej - uszkodzenie mieliny lub objawy mieszane [28]. Dokładny mechanizm toksyczności amiodaronu nie jest znany. Podobnie jak inne leki, amiodaron tworzy wewnątrzlizosomalne kompleksy lipidowe powodujące blaszkowate ciała wtrętowe w komórkach Schwanna, aksoplazmie oraz śródbłonkach naczyń nerwów [17, 25, 28]. Przewlekłe podawanie amiodaronu szczurom lub myszom powoduje podobne zmiany jak u ludzi wraz z dowodami ośrodkowej i obwo- 
dowej neurotoksyczności (modele zwierzęce toksyczności amiodaronowej) [29].

\section{Statyny}

Leki z grupy inhibitorów reduktazy 3-hydroksy-3-metylo-glutarylo-koenzymu A (HMG-CoA) - statyny - stosuje się w leczeniu zaburzeń gospodarki lipidowej [30, 31].

Statyny (lowastatyna, simwastatyna, prawastatyna, atorwastatyna, fluwastatyna oraz rozuwastatyna) sa powszechnie przepisywanymi lekami zmniejszającymi stężenie cholesterolu i ryzyko wystąpienia incydentów naczyniowo-sercowych. Leki te są zazwyczaj dobrze tolerowane [30, 31].

Do tej pory opisano nieliczne przypadki aksonalnej polineuropatii czuciowo-ruchowej po statynach. Objawem niepożądanym stwierdzanym znacznie częściej są miopatie.

Statyny moga być również przyczyną rabdomiolizy [32-34]. Częstość występowania powyższych objawów jest względnie niska i waha się od 4/100 000/rok w przypadku rabdomiolizy do 11-12/100 000/rok w przypadku neuropatii obwodowej i miopatii [35-37]. Mialgia wywołana statynami ma zróżnicowany charakter. Ból jest zazwyczaj uogólniony, zlokalizowany w obrębie kończyn dolnych i występuje po większym wysiłku mięśni. Decydujący wpływ na wystąpienie objawów ma dawka statyny.

O występowaniu powyższych objawów, oprócz dawki leku oraz współistnienia dodatkowych schorzeń predysponujących do uszkodzenia mięśni (jak cukrzyca, niedoczynność tarczycy czy częste infekcje), istotnie decydują właściwości farmakokinetyczne statyn i związane z nimi interakcje z innymi lekami, w tym z amiodaronem [20,33, 38].

\section{Leki stosowane w leczeniu przeciwnowotworowym}

Poniżej omówiono toksyczny wpływ leków przeciwnowotworowych na obwodowy układ nerwowy na przykładzie leków stosowanych w leczeniu szpiczaka mnogiego.

\section{Bortezomib}

Bortezomib, pochodna kwasu borowego, jest jednym z leków z wyboru w leczeniu szpiczaka mnogiego. Główny mechanizm działania bortezomibu (inhibitor proteasomu) polega na hamowaniu jądrowego czynnika transkrypcyjnego NF-кB, co wyzwala zjawisko zaprogramowanej śmierci komórki (apoptozy) [39].

Neurotoksyczne działanie bortezomibu powoduje zależną od dawki, bolesną, aksonalną, głównie czuciową polineuropatię, która charakteryzuje się osłabieniem wszystkich rodzajów czucia na obszarze "rękawiczek" i "skarpetek" [40]. Opisano pojedyncze przypadki poliradikuloneuropatii oraz neuropatii o charakterze demielinizacyjnym [41-43]. Uszkodzenie cienkich włókien powoduje palący lub kłujący ból stóp, często z przeczulicą, parestezjami i allodynią. Niekiedy występuje osłabienie czucia wibracji [44]. Zwykle stwierdza się osłabienie odruchów w kończynach dolnych, w których najwcześniej pojawia się osłabienie odruchów Achillesa. Rzadko dołączają się dystalne niedowłady mięśniowe, a zaburzenia czucia są bardziej nasilone niż osłabienie siły mięśni. Zazwyczaj stopień nasilenia polineuropatii wynosi od 1. do 3. (od niewielkiego do znacznego osłabienia siły mięśni odsiebnych kończyn dolnych). $U$ około $10 \%$ chorych (4. stopień polineuropatii) dochodzi do uogólnionego porażenia mięśni kończyn dolnych i znacznych niedowładów mięśni kończyn górnych [45]. Pojawiają się również objawy z zakresu autonomicznego układu nerwowego, takie jak ortostatyczne spadki ciśnienia krwi (u ok. 10\% chorych) [46].
We wczesnym okresie klinicznym w badaniu elektrofizjologicznym stwierdza się przede wszystkim uszkodzenie włókien czuciowych o charakterze aksonalnym. W wielu przypadkach pierwszym objawem jest uszkodzenie nerwu łydkowego [47]. W późniejszym okresie zmiany dotyczą zarówno włókien czuciowych, jak i ruchowych. Cechą charakterystyczną zapisów elektroneurograficznych jest obniżenie amplitudy czuciowych nerwowych i złożonych mięśniowych potencjałów czynnościowych oraz nieznaczne wydłużenie latencji końcowych. W badaniu EMG stwierdza się wszystkie cechy typowe dla neuropatii aksonalnej bardziej nasilone w mięśniach dystalnych, zwłaszcza unerwionych przez nerw strzałkowy $[48,49]$. W przypadku ostrzej przebiegającej neuropatii objawy odnerwienne (fibrylacje, dodatnie fale ostre) moga przeważać nad elektrofizjologicznymi cechami reinerwacji (duże amplitudy potencjałów jednostek ruchowych, wydłużony czas trwania, zwiększone pole i zwiększenie odsetka potencjałów wielofazowych) [50].

\section{Talidomid}

Talidomid został wycofany z użycia w 1961 r. z powodu znacznej teratogenności. Stosunkowo niedawno ponownie znalazł zastosowanie w leczeniu różnych chorób ze względu na właściwości immunomodulujące, przeciwzapalne i hamujące angiogenezę. Obecnie prowadzi się badania kliniczne oceniające skuteczność i bezpieczeństwo stosowania tego leku w zespołach dysplastycznych, chorobach układowych, nowotworowych i hematologicznych. Talidomid z dobrym skutkiem stosuje się w leczeniu opornej/nawrotowej postaci szpiczaka [51].

Często występującym objawem niepożądanym ograniczającym stosowanie tego leku jest czuciowo-ruchowa polineuropatia typu aksonalnego, występująca u od 50 do $70 \%$ wszystkich pacjentów leczonych talidomidem [52]. Talidomid powoduje zwyrodnienie aksonu o charakterze tzw. obumierania wstecznego (dying back) [53, 54], rzadziej obserwuje się zajęcie komórek zwojów korzeni grzbietowych [55]. W obrazie klinicznym dominuja objawy czuciowe w postaci drętwienia i mrowienia oraz bolesne kurcze łydek. Objawy ograniczają się początkowo do kończyn dolnych, następnie stopniowo obejmują również dystalne odcinki kończyn górnych. W zaawansowanej neuropatii dochodzi do uogólnionego osłabienia lub braku odruchów okostnowo-ścięgnistych [44]. Niekiedy występują objawy ataksji chodu związane z zaburzeniami czucia ułożenia. Neuropatia jest na ogół miernie nasilona, ale może mieć ciężki, nieodwracalny przebieg. Wystapienie polineuropatii zależy zwykle od dawki leku oraz od czasu trwania terapii $[56,57]$. W ostatnich latach opublikowano kilka prac oceniających korelacje między parametrami przewodzenia czuciowego a stopniem nasilenia objawów klinicznych chorych na szpiczaka mnogiego, ale wyniki tych badań nie są jednoznaczne [54, 58, 59].

Przeprowadzane okresowo badania elektrofizjologiczne znacznie zmniejszyły ryzyko wystąpienia ciężkiej nieodwracalnej neuropatii prowadzącej do niepełnosprawności.

\section{Ocena stopnia zaawansowania polekowych neuropatii}

Stopień zaawansowania polineuropatii można oceniać za pomocą badania klinicznego i elektrofizjologicznego [60]. Ocenę stopnia nasilenia zaburzeń czuciowych przeprowadza się zgodnie z kryteriami tzw. czuciowej neuropatii toksycznej (sNCl-CTC 3.0) [61].

Pacjenci z występującym wcześniej jakimkolwiek typem neuropatii wrodzonej czy nabytej wykazują znacznie większą podatność na wystąpienie neuropatii obwodowej 
polekowej. W takich przypadkach zalecane jest zmniejszenie dawki potencjalnie neurotoksycznego leku.

Możliwości leczenia bólu neuropatycznego u chorych na szpiczaka mnogiego z polineuropatią wywołaną talidomidem i bortezomibem przedstawiono w 2008 r. [62-64]. Propozycje te, z modyfikacjami, mogą znaleźć zastosowanie również w leczeniu pozostałych neuropatii polekowych.

\section{Podsumowanie}

Polekowe neuropatie stanowią coraz częstszy problem dotyczący zarówno pacjentów, jak i służby zdrowia. W praktyce lekarskiej coraz częściej obserwuje się negatywnie oddziałujące na układ nerwowy objawy niepożądane podstawowych leków opieki medycznej. Niewykryte i nieleczone neurotoksyczne objawy niepożądane mogą doprowadzić do trwałych zmian w obwodowym układzie nerwo- wym, upośledzając samodzielne funkcjonowanie pacjentów (niekiedy doprowadzając nawet do trwałego kalectwa), negatywnie oddziałując na przebieg terapii oraz wpływając ujemnie na samopoczucie i stan psychiczny chorych.

Podstawowymi zadaniami lekarza podstawowej opieki zdrowotnej powinny być wczesne rozpoznanie zaburzeń nerwowego układu obwodowego oraz skierowanie pacjenta na dokładne badanie neurologiczne. Współpraca lekarza podstawowej opieki zdrowotnej oraz neurologa umożliwia ustalenie wiarygodnego związku czasowego między przeprowadzoną terapią a wystąpieniem pierwszych objawów polineuropatii oraz pozwala na zmodyfikowanie terapii podstawowej w celu obniżenia neurotoksycznych objawów niepożądanych przy jednoczesnym zachowaniu podstawowych parametrów leczenia choroby pierwotnej (zmiana leku na równie skuteczny, lecz mniej neurotoksyczny; obniżenie dawki leku podstawowego; włączenie do terapii leków neuroprotekcyjnych).

Źródło finansowania: Praca sfinansowana ze środków własnych autorów.

Konflikt interesów: Autorzy nie zgłaszają konfliktu interesów.

\section{Piśmiennictwo}

1. Seretny M, Currie GL, Sena ES, et al. Incidence, prevalence, and predictors of chemotherapy-induced peripheral neuropathy: a systematic review and meta-analysis. Pain 2014; 155(12): 2461-2470.

2. Tisdale JE, Miller DA. Drug-induced diseases: prevention, detection, and management. Bethesda: ASHP; 2010.

3. Bainbridge JL. Experimental and clinical neurotoxicology. Am J Pharm Educ 2000; 64: 335.

4. Russell JW, Gill JS, Sorenson EJ, et al. Suramin-induced neuropathy in an animal model. J Neurol Sci 2001; 192(1-2): 71-80.

5. Hoke A, Ray M. Rodent models of chemotherapy-induced peripheral neuropathy. ILAR J 2014; 54(3): 273-281.

6. Weimer LH, Sachdev N. Update on medication-induced peripheral neuropathy. Curr Neurol Neurosci Rep 2009; 9(1): 69-75.

7. Camdessanche JP, Jousserand G, Ferraud K, et al. The pattern and diagnostic criteria of sensory neuronopathy: a case-control study. Brain 2009; 132(Pt 7): 1723-1733.

8. Ta LE, Espeset L, Podratz J, et al. Neurotoxicity of oxaliplatin and cisplatin for dorsal root ganglion neurons correlates with platinum-DNA binding. Neurotoxicology 2006; 27(6): 992-1002.

9. Preston DC, Shapiro BE. Electromyography and neuromuscular disorders: clinical-electrophysiologic correlations (expert consult-online). Elsevier Health Sciences; 2012.

10. Cata JP, Weng HR, Lee BN, et al. Clinical and experimental findings in humans and animals with chemotherapy-induced peripheral neuropathy. Minerva Anestesiol 2006; 72(3): 151-169.

11. Kimura J. Electrodiagnosis in diseases of nerve and muscle: principles and practice. Oxford: Oxford University Press; 2013.

12. Weiss LD, Weiss JM, Silver JK. Easy EMG: a guide to performing nerve conduction studies and electromyography. Elsevier Health Sciences; 2015.

13. Auer J, Berent R, Eber B. Amiodarone in the prevention and treatment of arrhythmia. Curr Opin Investig Drugs 2002; 3(7): 1037-1044.

14. Orr CF, Ahlskog JE. Frequency, characteristics, and risk factors for amiodarone neurotoxicity. Arch Neurol 2009; 66(7): 865-869.

15. Fraser $\mathrm{AG}$, McQueen $\mathrm{IN}$, Watt $\mathrm{AH}$, et al. Peripheral neuropathy during longterm high-dose amiodarone therapy. J Neurol Neurosurg Psychiatry 1985; 48(6): 576-578.

16. Hilleman D, Miller MA, Parker R, et al. Optimal management of amiodarone therapy: efficacy and side effects. Pharmacotherapy 1998; 18(6 Pt 2): 138S-145S.

17. Palakurthy PR, Iyer V, Meckler RJ. Unusual neurotoxicity associated with amiodarone therapy. Arch Intern Med 1987; 147(5): 881-884.

18. Ricaurte B, Guirguis A, Taylor HC, et al. Simvastatin-amiodarone interaction resulting in rhabdomyolysis, azotemia, and possible hepatotoxicity. Ann Pharmacother 2006; 40(4): 753-757.

19. Roten L, Schoenenberger RA, Krahenbuhl S, et al. Rhabdomyolysis in association with simvastatin and amiodarone. Ann Pharmacother 2004; 38(6): 978-981.

20. Saliba WR, Elias M. Myopathy from the combination of simvastatin and amiodarone. Eur J Intern Med 2006; 17(2): 148.

21. Raeder EA, Podrid PJ, Lown B. Side effects and complications of amiodarone therapy. Am Heart J 1985; 109(5 Pt 1): $975-983$.

22. Morady F, Sauve MJ, Malone P, et al. Long-term efficacy and toxicity of high-dose amiodarone therapy for ventricular tachycardia or ventricular fibrillation. Am J Cardiol 1983; 52(8): 975-979.

23. Kashyap AS, Anand KP, Kashyap S. Severe ataxia caused by amiodarone. Am J Cardiol 2006; 97(10): 1550-1551.

24. Phan T, McLeod JG, Pollard JD, et al. Peripheral neuropathy associated with simvastatin. J Neurol Neurosurg Psychiatry 1995; 58(5): 625-628.

25. Charness ME, Morady F, Scheinman MM. Frequent neurologic toxicity associated with amiodarone therapy. Neurology 1984; 34(5): 669.

26. Meier C, Kauer B, Muller U, et al. Neuromyopathy during chronic amiodarone treatment. A case report. J Neurol 1979; 220(4): 231-239.

27. Lustman F, Monseu G. Letter: amiodarone and neurological side-effects. Lancet 1974; 1(7857): 568

28. Pellissier JF, Pouget J, Cros D, et al. Peripheral neuropathy induced by amiodarone chlorhydrate. A clinicopathological study. J Neurol Sci 1984; 63(2): 251-266.

29. Jacobs JM, Costa-Juss F. The pathology of amiodarone neurotoxicity. Brain 1985; 108(Pt 3): 753-769.

30. Lamon-Fava S. Statins and lipid metabolism: an update. Curr Opin Lipidol 2013; 24(3): 221-226. 
31. Taylor F, Huffman MD, Macedo AF, et al. Statins for the primary prevention of cardiovascular disease. Cochr Database Syst Rev 2013; 1: CD004816.

32. Baker SK, Tarnopolsky MA. Statin-associated neuromyotoxicity. Drugs Today (Barc) 2005; 41(4): 267-293.

33. Bays H. Statin safety: an overview and assessment of the data - 2005. Am J Cardiol 2006; 97(8A): 6C-26C.

34. Gaist D, Jeppesen U, Andersen M, et al. Statins and risk of polyneuropathy A case-control study. Neurology 2002; 58(9): 1333-1337.

35. Jones $\mathrm{PH}$, Davidson MH. Reporting rate of rhabdomyolysis with fenofibrate + statin versus gemfibrozil + antystatin. Am J Cardiol 2005; 95(1): 120-122.

36. Cziraky MJ, Willey VJ, McKenney JM, et al. Risk of hospitalized rhabdomyolysis associated with lipid-lowering drugs in a real-world clinical setting. J Clin Lipidol 2013; 7(2): 102-108.

37. Gaist D, Rodriguez LA, Huerta C, et al. Lipid-lowering drugs and risk of myopathy: a population-based follow-up study. Epidemiology 2001; 12(5): 565-569.

38. Law M, Rudnicka AR. Statin safety: a systematic review. Am J Cardiol 2006; 97(8A): 52C-60C.

39. Chen D, Frezza M, Schmitt S, et al. Bortezomib as the first proteasome inhibitor anticancer drug: current status and future perspectives. Curr Cancer Drug Targets 2011; 11(3): 239-253.

40. Cavaletti G, Jakubowiak AJ. Peripheral neuropathy during bortezomib treatment of multiple myeloma: a review of recent studies. Leuk Lymphoma 2010; 51(7): 1178-1187.

41. Weimer LH, Sachdev N. Update on medication-induced peripheral neuropathy. Curr Neurol Neurosci Rep 2009; 9(1): 69-75.

42. Zivkovic SA, Lacomis D, Lentzsch S. Paraproteinemic neuropathy. Leuk Lymphoma 2009; 50(9): 1422-1433.

43. Argyriou AA, Iconomou G, Kalofonos HP. Bortezomib-induced peripheral neuropathy in multiple myeloma: a comprehensive review of the literature. Blood 2008; 112(5): 1593-1599.

44. Chaudhry V, Cornblath DR, Polydefkis M, et al. Characteristics of bortezomib- and thalidomide-induced peripheral neuropathy. J Peripher Nerv Syst 2008; 13(4): 275-282.

45. Gupta S, Pagliuca A, Devereux S, et al. Life-threatening motor neurotoxicity in association with bortezomib. Haematologica 2006; 91(7): 1001.

46. Richardson PG, Xie W, Mitsiades C, et al. Single-agent bortezomib in previously untreated multiple myeloma: efficacy, characterization of peripheral neuropathy, and molecular correlations with response and neuropathy. J Clin Oncol 2009; 27(21): $3518-3525$.

47. Richardson PG, Briemberg $\mathrm{H}$, Jagannath $\mathrm{S}$, et al. Frequency, characteristics, and reversibility of peripheral neuropathy during treatment of advanced multiple myeloma with bortezomib. J Clin Oncol 2006; 24(19): 3113-3120.

48. Chen $\mathrm{Cl}$, Kouroukis $\mathrm{CT}$, White $\mathrm{D}$, et al. Bortezomib is active in patients with untreated or relapsed Waldenström's macroglobulinemia: a phase II study of the National Cancer Institute of Canada Clinical Trials Group. J Clin Oncol 2007; 25(12): $1570-1575$.

49. Umapathi T, Chaudhry V. Toxic neuropathy. Curr Opin Neurol 2005; 18(5): 574-580.

50. Windebank AJ, Grisold W. Chemotherapy-induced neuropathy. J Peripher Nerv Syst 2008; 13(1): 27-46.

51. Hideshima T, Chauhan D, Shima Y, et al. Thalidomide and its analogs overcome drug resistance of human multiple myeloma cells to conventional therapy. Blood 2000; 96(9): 2943-2950.

52. Cavaletti G, Beronio A, Reni L, et al. Thalidomide sensory neurotoxicity: a clinical and neurophysiologic study. Neurology 2004; 62(12): 2291-2293.

53. Plasmati R, Pastorelli F, Cavo M, et al. Neuropathy in multiple myeloma treated with thalidomide: a prospective study. Neurology 2007; 69(6): 573-581.

54. Laaksonen S, Remes K, Koskela K, et al. Thalidomide therapy and polyneuropathy in myeloma patients. Electromyogr Clin Neurophysiol 2005; 45(2): 75-86.

55. Giannini F, Volpi N, Rossi S, et al. Thalidomide-induced neuropathy: a ganglionopathy? Neurology 2003; 60(5): 877-878.

56. Mileshkin L, Stark R, Day B, et al. Development of neuropathy in patients with myeloma treated with thalidomide: patterns of occurrence and the role of electrophysiologic monitoring. J Clin Oncol 2006; 24(27): 4507-4514.

57. Offidani M, Corvatta L, Marconi M, et al. Common and rare side-effects of low-dose thalidomide in multiple myeloma: focus on the dose-minimizing peripheral neuropathy. Eur J Haematol 2004; 72(6): 403-409.

58. Tosi P, Zamagni E, Cellini C, et al. Neurological toxicity of long-term ( $>1 \mathrm{yr}$ ) thalidomide therapy in patients with multiple myeloma. Eur J Haematol 2005; 74(3): 212-216.

59. Hess C, Hunziker T, Küpfer A, et al. Thalidomide-induced peripheral neuropathy. J Neurol 1986; 233(2): 83-89.

60. Moore CD. Management of chemotherapy-induced peripheral neuropathy. US Pharm 2015; 40(1): HS5-HS10.

61. Cavaletti G, Frigeni B, Lanzani F, et al. Chemotherapy-induced peripheral neurotoxicity assessment: a critical revision of the currently available tools. Eur J Cancer 2010; 46(3): 479-494.

62. Tariman JD, Love G, McCullagh E, et al. Peripheral neuropathy associated with novel therapies in patients with multiple myeloma: consensus statement of the IMF Nurse Leadership Board. Clin J Oncol Nurs 2008; 12 (3 Suppl): 29.

63. Bilińska M, Usnarska-Zubkiewicz L, Pokryszko-Dragan A. Bortezomib-induced painful neuropathy in patients with multiple myeloma. Contemp Oncol (Pozn) 2013; 17(5): 421-426.

64. Bilińska M, Usnarska-Zubkiewicz L, Szymczyk M, et al. Thalidomide-induced sensory neuropaty in patients with multiple myeloma. Pol Merk Lek 2011; 31(182): 86-91.

Adres do korespondencji:

Dr n. med. Marta Banach

Katedra Neurologii UJ CM

ul. Botaniczna 3

31-503 Kraków

Tel.: 607 933-567, 12 424-86-13

E-mail: martabanach@yahoo.com

Praca wpłynęła do Redakcji: 12.10.2015 r.

Po recenzji: 29.10.2015 r.

Zaakceptowano do druku: 29.10.2015 r. 